\title{
STRUCTURAL LIMITATIONS ON BANK COMPETITION
}

\author{
Tynan Smith* and Nathaniel Greenspun†
}

\author{
I \\ InTRODUCTION-THE NEEd For REgULATTON OF THE \\ Structure of BANKING
}

The preservation and strengthening of competition among banks and among all types of financial institutions is not an end in itself but rather is a means of achieving maximum service in the public interest from the financial industry. Competition is the dynamic force which results in economic efficiency in the broad sense. The competitive process rewards the progressive and efficient firms, encourages innovations in products and methods, and provides wide customer product choice at the lowest prices consistent with adequate returns to the factors employed.

The advantages of competition in banking are not essentially different from those in any other industry. The judgment of Congress and of history, however, is that the price of unrestrained competition is too high to pay in banking. Complete freedom to enter and freedom to fail, marks of unrestrained competition, cannot be permitted in the banking business. In past periods when such freedom existed, downturns in the business cycle were frequently aggravated by widespread bank failures. Since the 1930s, however, a major objective in bank chartering by both federal and state authorities has been to guard against "overbanking." The dangers of excessive competition have also been checked by other legal and regulatory devices, such as prohibition of payment of interest on demand deposits and limitations on the rate of interest paid on time and savings deposits, and various regulations on asset holding to prevent undue concentration in risky or illiquid assets.

The banking system is affected with the public interest to a much greater extent than most industries. On the national level, the banking system is an important influence upon the money supply, and sharp fluctuations in the money supply can have serious adverse effects on the economy. On the local level, the individual bank has a much more important role than the individual firm in most other industries. Failure of a bank will hurt not only its depositors but may have a serious impact on the entire economy of its trade area if the bank is of significant size. For these reasons it has been determined as a matter of public policy that the banking system

\footnotetext{
- Associate Adviser, Division of Research and Statistics, Board of Governors of the Federal Reserve System.

†Economist, Division of Research and Statistics, Board of Governors of the Federal Reserve System. The views expressed are those of the authors and do not necessarily reflect the views of the Federal Reserve Board.
} 
ought not to be subjected to competitive pressures of types or in degrees which lead to instability. The basic tenet is that the costs of this protective policy in terms of reduced efficiency are more than outweighed by the gains derived from a stable banking system.

Another function of the banking system that is of major importance to the public interest is its role as intermediary in the allocation of financial resources. Economic history has emphasized that this role can lead to control of other segments of the economy. This potential exists at the local, regional, and national levels. Fear of concentration of financial power was a major factor in President Jackson's successful fight against the second Bank of the United States. This same fear today motivates public concern over any trend toward concentration in banking. The maintenance of sufficient but not excessive competition has been accepted as the best means to assure in the public interest a rational allocation of financial resources among various bidders. ${ }^{1}$

From the public interest standpoint, therefore, there are two forces pulling in opposite directions with regard to competition in banking. The desire for stability and the fear of overbanking tend to limit competition, while the concern with concentration of financial power and the promotion of economic efficiency push in the direction of increasing competition. Thus, public regulatory policy must seek a compromise solution between these two sets of conflicting objectives.

Two factors internal to the banking system also play a major role in determining the degree of competition in banking. One is that economies of scale in banking appear to be attainable only to a limited extent; the other is that banking competition in most markets takes the form primarily of variations in and promotion of the services offered rather than of variations in the prices charged for credit or deposit services. The major role of nonprice competition in banking makes it very difficult to measure market performance and, consequently, to measure relationships between market structure and performance-for example, the effect on profits of different levels of market concentration. Since measurement is a prerequisite to comparison, the inability to rely primarily on the usual comparative price measures has been a major obstacle in evaluating performance in banking markets.

The problem of measuring performance may also be a major explanation of the limited results that have thus far been achieved in efforts to analyze economies of scale in banking. Such studies have focused on costs and earnings and have found evidence that costs decline as size of bank increases, particularly at the lower and upper ends of the size scale. The results have not been very striking, however, except in suggesting that very small banks-for example, those with deposits of less

\footnotetext{
${ }^{1}$ This point bas been made by many students of banking. See Roland Robinson's discussion of the optimum degree of competition in the financial system in his article, Economic Role and Objectives for California Banking and Financial Institutions, in CaLIFornia Banking IN A Growing Economy: 1946-1975, at 54-57 (H.P. Minsky ed. 1965).
} 
than $\$ 2$ million-are inefficient economic units. Over much of the size range, however, the evidence indicates only moderate economies of increasing size.?

Comparisons of unit and branch banks of similar size have shown higher costs for branch banks but a tendency for this to be offset by higher earnings for branch banks as a result of larger loan-to-deposit ratios and an investment of a larger proportion of loan portfolios in high-interest-rate loans such as instalment loans and mortgages. ${ }^{3}$

The existence of economies of scale and of differences between branch and unitbank types of operation has important implications for the optimal banking structure. It is imperative, therefore, to investigate these factors as fully as possible in order to provide a sound basis for public policy. Thus far, studies in this area have not adequately dealt with the analytical problems arising from the multiproduct mixture of services rendered by banks and from the geographical dispersion of bank customers. The optimal size of a bank serving a major financial center is not the optimal size of a bank serving a small rural community. Nor is a branch bank equivalent to a unit bank of the same size. Such factors must be carefully considered and weighed before conclusions can be reached on the direction banking structure should take.

Thus far in our history, however, legislative limitations on structure have probably played a more important role than economic factors in determining our banking structure. The existence of the dual banking system, whether created by historical accident or by design, has resulted in a complex of fifty state authorities and three federal agencies involved in determining entry, exit, branching, merger, and holdingcompany activity in the banking industry. ${ }^{4}$ A confusing variety of laws and regulations, often with conflicting objectives, control the structure of banking. The result is that change occurs slowly-but does occur. At present the crossing of state lines is not permitted via either branching or holding-company acquisitions. The prohibition has been questioned at least with respect to branching in those metropolitan areas which spill over into adjacent states. Many of the states are currently re-examining their banking legislation and revisions are being made.

The regulatory changes affecting banking structure that have been made in recent years are generally in the direction of liberalizing the ground rules to permit the establishment of larger banking organizations. We are, however, still a nation of small banks. At the end of $x 965$, the number of commercial banks equaled $x_{3}, 800$. This total was only three per cent less than the 1945 total of 14,200 . The degree of concentration in the banking business has also not changed very much. At the end of 1965 , the hundred largest banks held a little less than fifty per cent of all commercial bank deposits, about the same as twenty years earlier. The most striking

${ }^{2}$ See J. M. Gutrentag \& E. S. Herman, Banking Structure and Performance ch. 5 (1967).

Id.

¿ See generally Symposium-Banking Regulation, 3I LAw \& Contemp. Pros. 635 (1966). 
change during the same twenty-year period has been the increase in the number of banking offices from 18,200 in 1945 to 29,750 in 1965 .

II

\section{Entry Into the Banking Business}

Complete freedom of entry into the banking business was never permitted in the United States, although during the early "wildcat banking" period we came painfully close to allowing it. Before the Great Depression, restrictions on bank entry were primarily designed to prevent abuses of the public trust aspects of banking. Generally thought to be sufficient for this purpose were the evaluation of the character and competence of the organizers and prospective managers of a new bank, the imposition of minimum capital requirements, and the establishment of certain operating restrictions. With the dual banking system, even these restrictions tended to be watered down as a result of the competitive chartering activities of the national and state authorities. But with the revision of the banking laws in the early rg3os, concern with overbanking became the paramount consideration in restricting bank entry. Major blame for the wave of bank failures that culminated in the Bank Holiday in March I933 was placed on excessive bank chartering between I900 and I920. Consequently, an additional requirement for bank entry was established in the Banking Acts of 1933 and 1935 for coverage of banks under the deposit insurance system. It was required that the Comptroller of the Currency, for newly organized national banks, and the Federal Reserve Board, for newly admitted state member banks, certify to the Federal Deposit Insurance Corporation that they had considered, in addition to management and financial condition, the new bank's "future earnings prospects ... [and] the convenience and needs of the community to be served by the bank." "The FDIC was required to consider the same factors before accepting state banks not members of the Federal Reserve System. ${ }^{7}$ Since very few commercial banks felt that they could operate successfully without deposit insurance, the consideration of earnings prospects and convenience and needs has become applicable to nearly all new bank applications since 1935 .

The new legislation, in effect, gave the federal supervisory authorities a veto power over state chartering of new banks. The "veto," however, was little used. Rather, the "need" criterion for the establishment of new banks was generally accepted by all of the bank chartering authorities after the Banking Holiday. And, naturally enough, they were strongly supported in this direction by the bankers themselves who were anxious to discourage further competition. For the next twenty years "insufficient need" and "unfavorable earnings prospects" were very frequent reasons for denying applications for new bank charters. The effect, whether intended or not, was to confirm the position of the existing banks in their markets.

\footnotetext{
${ }^{5}$ Cf. Alhadeff, Reconsideration of Restrictions on Bank Entry, 76 Q.J. Ecos. 246, 248-49 (1962).

- 12 U.S.C. $\$ 518 \times 4,1816$ (1964).

7 I2 U.S.C. $\$ \$ 1815-16$ (1964).
} 
In an effort to determine whether bank entry restrictions had been effective, a study undertaken by Sam Peltzman compared the rate of bank entry in relation to economic variables for the period prior to I935 with the period after $1935 .^{8}$ From his analysis he concluded that the entry rate during the $1936-62$ period would have been from fifty to over Ioo per cent greater in the absence of regulation. This translates into about 2,200 more banks entering the business in the twenty-seven years r936-62, an impressive measure of the impact of the "need" criterion.

During the late I950s the concern with overbanking began to be replaced by concern for the maintenance of competition, with the result that attitudes toward new bank entry were liberalized. The Comptroller of the Currency made clear his views that bank chartering should be increased to help satisfy the needs of the public for additional banking facilities. ${ }^{10}$ In the three years $1962-64$, national bank charters were granted to 434 new banks, almost twice the total number of national charters granted in the previous decade. The state authorities, who had been granting charters at about three times the average rate for national charters in the 1950s, also increased their chartering activities but less spectacularly. Their average for $1962-64$ was 130 a year, or not quite twice the seventy-five per year average of the previous decade. Application of Peltzman's analysis indicates a rate of entry in this recent period substantially greater than would have been expected on the basis of his preI935 relationship. This suggests a "catching-up" period for new bank chartering that will not continue very long even if entry requirements remain liberalized.

Restrictions on entry were largely motivated by the desire to prevent bank failures. While there has always been a fear of bank failures because of their serious economic effects, that fear became almost pathological after the Great Depression. The FDIC was created to protect those with small deposits against the economic hardship of bank failure. Those with large deposits have also benefited from the FDIC's use of the deposit assumption method, in which deposit liabilities and assets of the failing bank are assumed by another bank but with the FDIC taking over any unacceptable assets. Under this procedure, all depositors gain complete protection. Since the shakeout of the banking system in the I930s, bank failures have been few and far between, but the fear of bank failures is still with us. A handful of bank failures in 1964 -seven in all-was sufficient to create considerable consternation and to generate a congressional inquiry.

It has been argued that, with the FDIC to protect depositors from most of the effects of bank failure, we could enjoy the benefits of the more actively competitive banking markets that would result from freer entry since the concomitant of more frequent failure would be softened by deposit insurance. ${ }^{11}$ The present policy

\footnotetext{
${ }^{8}$ Peltzman, Banking Entry Regulation: Its Impact and Purpose, 3 Nat'L Banking Rev. I63 (1965).

Id. at 172 .

${ }^{10} \mathrm{Id}$. at 175 .

${ }^{11}$ Cf. Alhadeff, supra note 5, and Jacobs, The Frameswork of Commercial Bank Regulation: An Ap-
} 
of applying the "need" criterion on entry and exerting every effort to prevent failures, it is further argued, results in protecting banking institutions that are poorly managed or too small to be efficient. By restricting entry on grounds that the existing market will not support another bank, we may indeed be foreclosing to more efficient institutions the opportunity to enter a market and depriving the public of the benefits of this efficiency. Existing banks are being given exclusive rights to their banking markets as long as they operate with reasonable regard for the public and avoid any disastrous errors of judgment. The foregoing rationale for liberalizing the rules of bank entry has, however, thus far achieved only limited acceptance in practice.

\section{III}

\section{Market Extension: Branches, Mergers, and Holding Companies}

Entry restriction is only one of the structural limitations imposed on the banking industry. The efforts of existing banking organizations to extend the geographical areas they serve are subject to restrictions that regulate branching, merger, and holding-company acquisitions. While very large banks in the major metropolitan centers do serve large corporate customers throughout the United States, banking is also an industry importantly dependent upon local markets of relatively small geographic area. In these markets, banks compete for the deposit and loan business of households and smaller firms. Market extension to serve such customers usually requires physical entry into individual geographic markets.

The restrictions on the various approaches to market extension have preserved the large number of smaller banks now operating in the United States and have prevented the development of banking organizations comparable in the geographic scope of their operations to grocery chains like A\&P and Safeway. In the process, however, the restrictions have probably imposed on our economy a burden of maintaining a large number of small, inefficient banks and have limited the banking structure's ability to adapt to the changing needs and growing demands of industrial expansion.

Branching, merger, and holding-company acquisitions are, to a considerable extent, alternative approaches to market extension. The opening of new branches, however, is more frequently conducive to the maintenance of competition and competitive markets than either branching by merger or holding-company expansion by the acquisition of existing banks. The approach selected in any given market, however, depends upon the state and federal restrictions imposed.

\section{A. Branching}

State laws regulating the establishment of branches of commercial banks are quite varied, ranging from complete freedom to complete prohibition. In general,

praisal, in U.S. Treasury Dep't, Studies in Banking Competition and the Banking Structure 337 (Ig66). 
however, the laws may be grouped into three types: statewide branching, limited branching, and unit banking (prohibition of branches). Fifteen states and the District of Columbia place either no restrictions or no restrictions of any significance on branching. These states are mostly in the western part of the country, but a few are located on the east coast. There are eighteen states which allow branching within narrow limits, usually the city and county in which the head office is located, and sometimes in contiguous counties. Almost all of these states are in the eastern third of the country. In seventeen states branching is not permitted, except for drive-in windows near the head office or, in a few states, for offices limited to such services as receiving deposits and cashing checks. The midwestern section of the country is largely characterized by unit banking. Also included in this category are Florida and West Virginia as well as some of the south central states.

Until recently, branching policy for national banks adhered without question to the limitations imposed by the states in which they were located. Former Comptroller of the Currency Saxon, however, challenged these restrictions. He argued that the state law in Utah which permitted branching anywhere in the state only through merger or purchase was merely a procedural requirement that national banks could ignore. Consequently, he approved applications to establish de novo branches which were prohibited by state law. These actions were challenged in the courts, and the Supreme Court rendered an opinion which reaffirms the overriding control of state law regarding branching of both state and national banks. ${ }^{12}$ The opinion concludes: "It appears clear ... that Congress intended to place national and state banks on a basis of 'competitive equality' insofar as branch banking was concerned."13

Mr. Saxon also challenged the laws regarding branching in those states which permit savings and loan associations to branch but not commercial banks. He argued that in such states savings and loan associations may be considered "state banks" for branching purposes. Wisconsin was selected for testing this interpretation of the law. The case is still pending before the U.S. District Court. ${ }^{14}$ In view of the strong opinion of the Supreme Court in the Utah cases, however, it is unlikely that Mr. Saxon's interpretation of the law will be upheld in the Wisconsin case.

The differences in state laws regarding branches have resulted in dramatic differences in banking structure. Unit-banking states generally have more banks in relation to population than do states that permit branch banking. Illinois and Texas, which do not permit branching, have about twice as many banks as Ohio and Pennsylvania, which have about the same population but permit limited branching. California, a statewide-branching state with a substantially larger population, has only a fifth as many banks as Illinois or Texas and less than one-half as many as Ohio or Pennsylvania.

\footnotetext{
${ }^{12}$ First Nat'l Bank of Logan v. Walker Bank \& Trust Co., 385 U.S. 252 (Ig66).

${ }^{13} \mathrm{Id}$. at $26 \mathrm{r}$.

${ }^{14}$ American State Bank v. Saxon, complaint filed, Civ. No. I82-66, D.D.C., Jan. 25, I966.
} 
As would be expected, most of the statewide-branching states have a higher ratio of offices to population than the national average. This is not true of the limitedbranching states, however. The more populous of these states-Massachusetts, New York, Ohio, and Pennsylvania-have fewer banking offices in relation to population than the national average. This probably reflects, in part, the greater concentration of population in the metropolitan areas of these states, since banking offices can conveniently serve a greater number of customers in densely populated areas than in sparsely settled regions.

The unit-banking states show the largest variation in the relationship of number of banking offices to population. Included in this group are Florida with the lowest ratio of offices to population and South Dakota with the highest ratio. It is apparent from this wide diversity that state branching law is only one factor in determining the development of banking structure. Population density and industrial and economic developments also play major roles.

\section{B. Mergers}

Until rg60, bank mergers were subject to control almost exclusively through state laws. Such laws generally required approval of the state banking authority, but the objective was primarily to protect the interests of the stockholders and the depositors and relatively little attention was paid to the competitive impact. Neither were most mergers regarded as being affected by the Clayton and Sherman antitrust statutes.

The Bank Merger Act of $1960^{15}$ made the mergers of all insured commercial banks subject to the control of the federal bank supervisory authorities. Final authority for approval was given to the Comptroller of the Currency, the Federal Reserve Board, or the Federal Deposit Insurance Corporation, depending on whether the resulting bank would be a national bank, a state-bank member of the Federal Reserve System, or an insured nonmember state bank. The act provided a set of criteria to be considered by the responsible banking agency. In addition to several "banking factors," which included management qualifications, capital condition, and earnings prospects of the merging banks, the criteria also called for consideration of both the impact of the proposed merger on competition and the effect on convenience and needs of the communities involved.

The belief that the federal banking agencies had been given final authority over bank mergers was rudely shattered by the 1963 and 1964 decisions by the Supreme Court in the Philadelphia National Bank ${ }^{16}$ and Lexington ${ }^{17}$ cases, which ruled that bank mergers were subject to the standards of both the Sherman Act ${ }^{18}$ and section 7

\footnotetext{
${ }^{15}$ Pub. L. No. 86-463, 74 Stat. I29.

${ }^{10}$ United States v. Philadelphia Nat'l Bank, 374 U.S. 321 ( 1963 ).

${ }_{17}^{17}$ United States v. First Nat'l Bank \& Trust Co. of Lexington, 376 U.S. 665 (1964).

${ }^{18} 15$ U.S.C. $\$ \S \mathrm{I}-7$ (Ig64).
} 
of the Clayton Act. ${ }^{19}$ These decisions stimulated Congress to reconsider the bank merger question and resulted in the passage of the Bank Merger Act of $1966^{20}$

The standards set forth in the new law reaffirm the applicability of the antitrust laws to bank mergers, but soften their impact by providing that substantially adverse competitive effects of a proposed merger can be "clearly outweighed in the public interest by the probable effect of the transaction in meeting the convenience and needs of the community to be served." Again, as under the Bank Merger Act of 1960 , advisory reports on competitive effect are required from the other banking agencies and the Justice Department.

Except in certain emergency situations, the new law requires a thirty-day waiting period following agency approval during which the Justice Department may sue to enjoin the proposed merger. ${ }^{22}$ If no suit is instituted during the thirty-day period, the proposal may be consummated, and the merger is thereafter specifically exempt from any antitrust proceeedings, except under the antimonopoly provisions of section 2 of the Sherman Act. ${ }^{23}$ The new law also required that in any judicial proceeding attacking an agency-approved merger, the standards to be applied by the courts were to be the same as those applied by the banking agencies.

Although under the new law federal bank supervisory authorities still have primary responsibility for bank mergers, their administrative determinations carry no special weight in later judicial proceedings brought under the antitrust law. In the first test of the new law, the 1967 case of United States v. First City National Bank of Houston, ${ }^{24}$ the Comptroller and the banks had contended otherwise. They argued that the administrative ruling should be sustained unless the agency's action is not supported by substantial evidence. The Supreme Court admitted that this standard was "familiar in administrative procedure" applicable in antitrust actions. The Court first noted that in the Philadelphia National Bank and Lexington cases, both decided prior to the 1966 act, the administrative determination had been given no special weight. Next, Justice Douglas turned to the statutory language that "the standards applied by the court shall be identical with

\footnotetext{
${ }^{10} 15$ U.S.C. $\$ 18(1964)$.

${ }^{20} 12$ U.S.C. $\$ 828$ (c) (Supp. II, I965-66), formerly 74 Stat. 129 (I960).

21 I2 U.S.C. $\$ 1828$ (c) (5)(B) (Supp. II, r965-66). One issue raised by the new law was whether the Government or the banks have the burden of proof to show the effect of the merger on the convenience and needs of the community. This question was recently resolved by the Supreme Court in United States v. First City Nat'l Bank of Houston, 386 U.S. 36r ( 1967$)$. Rejecting the Comptroller's and the Banks' contention that the Justice Department was required to prove the absence of any offsetting community "convenience and needs," the Court ruled that "the banks carry the burden." Id. at 366.

${ }^{23}$ I2 U.S.C. $\$ 1828$ (c)(7)(A) (Supp. II, I965-66). Lawyers have found this provision rcmarkable because it gives the Department a "veto," to be exercised during the 30 days allowed for the institution of a suit, over consummation of the merger. Previously, the Department could obtain a preliminary injunction against consummation of the merger during litigation only by establishing to the court's satisfaction some irreparable harm and a reasonable probability of ultimate success on the merits.

${ }^{23}$ I5 U.S.C. $\$ 2(1964)$.

24 386 U.S. $36 \mathrm{I}(1967)$.

${ }^{25} I d$. at 367 .
} 
those that the banking agencies are directed to apply"26 and that in an antitrust action the court is directed to consider "de novo the issues presented."27 From this they concluded: $:^{28}$

The courts may find the Comptroller's reasons persuasive or well nigh conclusive. But it is the court's judgment, not the Comptroller's, that finally determines whether the merger is legal. That was the practice prior to the 1966 Act; and we cannot find a purpose on the part of Congress to change the rule.

Thus, the Justice Department remains the guardian of the public interest in cases involving antitrust issues, and its role has not been significantly changed by the rg66 act. ${ }^{20}$

It will take some time for the revised merger standards and procedures to be completely worked out and tested by the agencies and the courts. But there is little reason to believe that the typical merger will be treated much differently under the new standards than formerly. Most of the approximately I50 mergers a year that have come before the bank supervisory agencies have not involved substantial anticompetitive effects. A partial explanation for this may be the deterrent effect of such factors as present and past statutory restrictions and consequent regulatory agency disinclination to approve mergers that would have substantial anticompetitive effects. Another deterring factor of great importance has of course been the Justice Department's actual and threatened challenges in the courts of applications approved or under consideration by the supervisory authorities. Since the preparation of a formal merger application involves considerable expense for legal work and the preparation of supporting data, merger proponents ordinarily do not wish to file an application unless they are reasonably certain of approval. Consequently, merger proposals involving obviously significant anticompetitive effects, actual or potential, are not apt to be filed unless the applicant believes these effects can be "clearly outweighed."

There are also important economic reasons explaining the absence of substantial anticompetitive effects in most bank mergers. In many situations the acquiring bank is primarily interested in extending the geographic area it can serve by converting the acquired bank's offices into additional branch locations. From the buyer's point of view, the acquisition of branch offices through merger has several advantages over de novo branching. A branch acquired by merger is usually a profitable operation from the outset; the bulk of operating personnel are usually acquired along with the financial and other assets; and no long development period is required. A merger gives the acquiring bank an established market position in the new area, whereas a de novo branch would usually have to struggle to wrest a worthwhile share of the banking business from the banks already operating in the area. Furthermore, most

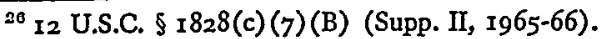

${ }^{27}$ I2 U.S.C. $\S$ I828(c) (7) (A) (Supp. II, I965-66).

${ }_{28} 386$ U.S. at 366 . (Emphasis added.)

${ }^{20}$ See note 21 supra.
} 
of the favorable bank locations in an area may be pre-empted by existing banks thus making de novo entry still more difficult and risky.

In addition to the economic factors favorable to branching by merger there are often regulatory factors pushing in the same direction. Supervisory approval of a merger which extends the area served by a bank is sometimes easier to obtain than approval of a de novo branch application because of concern with overbanking. In many states the "home office protection" rule prevents the opening of a de novo branch at locations into which branch entry by merger would be permitted. In states such as Virginia, de novo branching is permitted only in the area near the head office, but branches can be acquired by merger anywhere in the state. Other states restrict branching to a less than statewide basis and also prohibit de novo branching in any municipality in which a bank is already in operation.

The motivations of the seller in many merger transactions frequently are explained by the small size of the acquired banks. Such banks are often unable to compete effectively with larger banks; small size is usually accompanied by low lending limits and by an inability to offer more than a limited range of banking services. Smaller banks often have but limited access to the capital needed for expansion, and frequently encounter difficulties in providing for management succession. Merger generally offers the easiest and most attractive solution to all of these problems. From the supervisory point of view, replacement of such marginal banks with branch offices of large, full-service banks frequently results in major improvement in the number and quality of services offered to the community served.

Since most bank mergers are a vehicle for acquiring branches, their geographic incidence is closely related to state branching laws. Over the last fifteen years, relatively few bank mergers have occurred in the central part of the country where unit banking prevails. The states which permit statewide branching have less than a tenth of the banks in the country, but have accounted for over one-fourth of the mergers. States permitting limited branching have nearly two-fifths of the nation's banks, but have accounted for over three-fifths of the mergers.

\section{Holding Companies}

An alternative to bank market extension through de novo branching or merger is expansion through so-called group banking. This involves the ownership or control of two or more banks and can be accomplished either by means of a holding company or, on a less formal basis, by an individual or group of individuals. The latter arrangement, known as "chain banking," is subject to no federal control and little or no state regulation.

Bank holding company organization and expansion is subject to both state and federal regulation. In 1956 the Federal Reserve Board was given authority to pass on all applications for the formation of new bank holding companies and acquisitions 
of additional banks by existing bank holding companies. ${ }^{30}$ For the purposes of the statute, holding companies were defined as companies owning twenty-five per cent or more of the voting shares of two or more banks. The regulatory standards to be applied were much the same as those later applied to bank mergers. In Ig66, the Bank Holding Company Act of 1956 was amended to parallel the wording of the 1966 amendment to the Bank Merger Act. ${ }^{31}$ As a result, the major emphasis in both bank merger and holding-company regulation is now explicitly placed on the prevention of adverse competitive effects.

Bank holding companies have developed in greatest numbers and are growing most rapidly in those states that either prohibit or limit branching activities. The holding company offers many of the operating advantages of branch banking, such as specialized services, development of management talent, and, to a degree, more efficient intrasystem allocation of financial resources. It is a less centralized organization than a branch system, however, and it is probably significant that in areas where the option is available, bankers themselves appear to prefer branch banking to holding-company operation. An important benefit of the holding-company form of organization is that it can retain a high degree of local autonomy for its affiliates while achieving at least some of the benefits accruing to a large branching organization. This is particularly advantageous when the holding-company operation extends over broad areas. ${ }^{32}$

A recent study of the performance of banks acquired by holding companies found no significant differences between these banks before acquisition and other banks of comparable size operating in the same general area. ${ }^{33}$ After acquisition, however, the holding-company banks achieve higher ratios of loans, especially instalment loans, and of state and local securities to total assets and lower ratios of cash items and U.S. Government securities. The higher operating earnings appeared to be largely offset, however, by an increase in expenses, chiefly in the category including fees and charges levied by the holding company for various services provided to the affliates.

Recent holding-company expansion has been of particular interest in Virginia and New York. The rapid expansion of holding companies in Virginia began in Ig62, after a minor liberalization in the state's limited branching privileges was enacted. This liberalization, however, did not include de novo branching on a statewide basis but confined it to the area near the bank. Although statewide branching by merger was permitted under Virginia law, the acquisition of a bank and its conversion into a branch did not result in the retention of the de novo branching privileges formerly enjoyed by the acquired bank. In the case of holding companies, however, a newly acquired affiliate retained its limited branching privileges as if it

\footnotetext{
${ }^{80}$ Bank Holding Company Act of 1956 , ch. 240, 70 Stat. 133.

31 12 U.S.C. $\$ \$ 184 I-49$ (1964, Supp. II, 1965-66).

22 For an excellent discussion of the nature of bank holding company operations and a history of group banking in the United States, see G. C. Fischer, Bank Holdnng Companies (rg6r).

${ }^{83}$ R. J. Lawrence, The Performance of Bank Holding Companies (I967).
} 
remained an independent bank. As a consequence, the holding-company form of organization held an important advantage over branch systems. A holding company, for example, through the acquisition of a sufficient number of strategically located banks could develop the virtual equivalent of statewide de novo branching privileges. While branch banking has also expanded at a rapid pace in Virginia, the holdingcompany form of organization made particularly rapid strides subsequent to 1962 . At that time, only two bank holding companies operated in Virginia. They comprised only nine affiliate banks. Within the next five years two additional holding companies were organized, and over thirty additional banks became members of holding-company groups. All of the large cities in the state have two or more of the holding companies competing, and several of the groups have spread through major areas of the state.

Since branching in New York state is substantially confined within boundaries of nine districts, except for some greater leeway in the New York City area, the holding company is the principal means available in New York to develop statewide or regional banking organizations. Until early 1966 , however, Marine Midland had been the only major holding company in the state, and it was oriented to upstate areas with only a moderate-sized affiliate in New York City. The 1962 attempt by the Morgan Guaranty Trust Company of New York City to form a holding company with six upstate New York banks had been turned down by the Federal Reserve Board on the ground that the proposal involved too many of the large upstate banks. ${ }^{34}$ Subsequently, however, Irving Trust and Bankers Trust organized considerably more modest combinations and were successful in gaining approval in April $1966{ }^{35}$ Other holding-company proposals which included only upstate banks have also been approved, and there are indications that within a few years most of the larger upstate New York banks will be affiliated with holding-company organizations either as lead banks or constituent elements.

The bank holding company is now an importantly used approach to bank market extension. Recent successes with this device have stirred up interest in those areas where branching restrictions leave holding companies as the preferred if not the only means of operating multiple location banking organizations. Should branching laws be liberalized, however, the use of the bank holding company will probably decline. But until such occurrence, the spread of holding-company affiliations may be expected to continue.

\section{IV}

\section{Analysis of Recent Merger and Holding-Company Cases}

To illustrate the regulatory interaction of branching, merger, and holdingcompany regulation, six merger and holding-company cases recently decided by the

\footnotetext{
${ }^{36}$ Morgan New York State Corp., 48 Fed. Reserve Burl. 567 (1962).

${ }^{35}$ Charter New York Corp., 52 Fed. Reserve Buld. 527 (1966); BT New York Corp., 52 Fed. Resenve BuLz. 5 II $_{7}$ (1966).
} 
Board of Governors have been selected for review. The first two cases illustrate the functioning of statutory barriers to merger and holding-company expansion. The first of these cases involved a merger proposal by the third largest bank in California, which sought to acquire a relatively small bank, but the application was denied. The second case resulted in denial of approval of a proposed acquisition of the second largest bank in St. Louis by a holding company already controlling the fourth largest bank in the metropolitan area as well as five others.

The remaining four cases illustrate the varying ways in which branching restrictions affect decisions in merger and holding-company cases. In the first of these cases, which involves two banks in Elkhart, Indiana, restrictions on branch banking and the prohibition of holding companies were primarily responsible for Board approval of a merger with substantial adverse competitive effects. In the second of these cases, the frequently encountered barriers to market extension resulting from home office protection are illustrated by merger proposals in which a Westchester County, New York, bank sought to extend the area it served into neighboring counties. The third case illustrates a much less frequently occurring situation, in which the merger of two New Jersey banks probably would not have been approved in the absence of home office protection. The final case also illustrates how restrictions on branching tend to inhibit the development of more competitive market structures even when the need for an additional competitor is recognized by the regulatory authority.

\section{A. The Maintenance of Competitive Market Structures}

\section{r. Wells Fargo-Bank of Sonoma County ${ }^{38}$}

In this I 966 case, Wells Fargo Bank, a $\$ 3.5$ billion, San Francisco-headquartered institution with over 200 branches in northern and central California, sought unsuccessfully to acquire the $\$ 17$ million Bank of Sonoma County, which had its main office in Sebastopol and operated two branches in nearby smaller communities. Wells Fargo operated no offices in any of the communities in which the Bank of Sonoma County had its offices, but the acquiring bank did operate three offices in Santa Rosa, a community eight miles distant from Sebastopol. At the time of the application, the only competition in Sebastopol for the acquired bank was a branch of the Bank of America, California's largest bank, which also operated offices in Santa Rosa. Besides Wells Fargo and the Bank of America, Santa Rosa was served by branches of three other large California banks, by an independent bank with deposits of about $\$ 5^{\circ}$ million, and by a very small, newly-chartered independent bank.

Despite the eight-mile distance between the nearest office of Wells Fargo and the head office of the Bank of Sonoma County, a distance often sufficient to rule out

\footnotetext{
${ }^{30}$ Wells Fargo Bank, 52 Fed. Reserve Bull. 655 (I966). Figures used in case discussions refer to total deposits as of mid-year or end-of-year dates prior to the decisions.
} 
effective competition, the Board with but one dissent denied the application on the grounds that the merger would eliminate both "existing and potential competition between the merging banks."

With respect to existing competition between the two banks, the Board found that "each bank derives a portion of its business from areas served by the other." As evidence that the two banks were potentially in competition with each other, the Board noted, "The towns are connected by good roads. Santa Rosa is by far the largest commmunity and trading center in the region. About one-third of the residents of Sebastopol commute to work, most of them to Santa Rosa." The Board then concluded that "the relevant area for the purpose of considering the effect of the proposal on competition is the combined Sebastopol/Santa Rosa area."

In analyzing the competitive effects of the proposal in the combined area, the majority emphasized the market shares in the combined Santa Rosa/Sebastopol area of the acquired bank, of the acquiring bank, and of their chief competitor, the Bank of America, California's largest bank. The Board specifically noted that "the three offices of Wells Fargo presently account for $3^{\mathrm{r}}$ per cent of the loans and 23 per cent of the IPC deposits held by the banking offices in the Sebastopol/Santa Rosa area" and that "after the proposed merger, the offices of Wells Fargo would account for 39 per cent and 33 per cent, respectively, of such loans and deposits." It was also pointed out that "after the proposed merger, Wells Fargo and Bank of America ... together would account for $6_{3}$ per cent of the loans and $6_{3}$ per cent of the IPC deposits held by all banking offices in the relevant area." ${ }^{\text {"37 }}$ These findings relating to competition between the two banks and concentration in the Sebastopol/Santa Rosa area were the basis for the Board's conclusion that the effect of the proposal on competition "would be adverse."

In analyzing convenience and needs, the Board noted that "the principal reason advanced in support of approval of the proposed merger is that Sonoma Bank is unable to satisfy the credit needs of the Sebastopol community." Rejected by the Board, however, was the argument that an individual bank's inability to meet all of the loan demands made upon it was sufficient reason to justify merger with a bank already serving the area, albeit from a less convenient location. The Board observed that the Sebastopol community was directly served by a branch of the Bank of America and was also served by various bank offices in nearby Santa Rosa. Their opinion agreed that the merger "would ... benefit to some degree the convenience of Sebastopol residents by providing a closer alternative source of loan funds and other banking services" but emphasized that "there is a lack of persuasive evidence that the existing ... or ... future banking needs of the community will not be adequately served."

In balancing considerations of convenience and needs and competitive effect, the

\footnotetext{
${ }^{87}$ IPC deposits consist of time and demand deposits of individuals, partnerships, and corporations.
} 
Board emphasized that the proposal "would be accompanied . . . by the elimination of competition between the merging banks and, more importantly, by an increase in the strength of Wells Fargo, a bank which is already one of the dominant forces in the relevant market area." This appraisal of competitive effects was more than sufficient to justify denial inasmuch as the Board had concluded that the proposal's benefits to convenience and needs would be no more than a limited benefit to the convenience but not the needs of Sebastopol residents.

The Board's denial in this case relies on the finding that both banks were serving and potentially could serve the same market. Important to note, however, is that the Board defined the market as the entire Sebastopol/Santa Rosa area although the nearest offices of the banks involved were eight miles apart. It is the fairly broad geographic definition of the market employed by the majority and the recognition of potential competition which makes the case a strong precedent.

An aspect of potential competition not spelled out in the opinion was that California law permits de novo branching anywhere in the state. Wells Fargo could have become a direct competitor in the Sebastopol area through the establishment of a branch in Sebastopol itself. This of course might be considered the principal potential competition eliminated if the proposal were approved since Wells Fargo, on the basis of its local deposit and loan share, could be regarded as the single most probable potential entrant into Sebastopol.

Excluding the Bank of America, which already operated offices in both Sebastopol and Santa Rosa, and also excluding Wells Fargo, there were five banks with offices in Santa Rosa but not in Sebastopol which could be considered potential entrants into Sebastopol through de novo branching. Of these five banks, three were large branch systems ranking among the top seven California banks. The three banks were Crocker-Citizens National Bank, United California Bank, and Bank of California. In total deposit size, these banks ranged from $\$$ I.2 billion to $\$ 3.3$ billion. Within the Santa Rosa/Sebastopol area, however, the $\$ 3.5$ billion Wells Fargo accounted for a very much larger share of both loans and deposits than the three branch systems with offices in Santa Rosa but not in Sebastopol. The Wells Fargo share of area loans equaled thirty-one per cent; its share of area deposits, twenty-three per cent. By contrast, the three branch banks accounted for a combined deposit share of nine per cent and a combined loan share of eleven per cent. These differences in market share lend additional support to the Board action in denying the proposal.

\section{General Bancshares Corporation ${ }^{38}$}

The General Bancshares case of late Ig66 represents a confirmation that the Board will not approve holding-company applications that eliminate significant existing competition in a given market area. The case involved the proposal of the General Bancshares Corporation to acquire the second largest bank in St. Louis, the \$7I2

\footnotetext{
${ }^{88}$ General Bancshares Corp., 53 Fed. Reserve Burl. 65 (I967).
} 
million First National Bank. The bank to be acquired was located in the central business district of downtown St. Louis. At the time the proposal was made, General Bancshares had a total of ten subsidiary banks with total deposits of $\$ 367$ million. Six of these ten subsidiary banks were located in Missouri, all in the St. Louis metropolitan area. The principal basis for the Board's denial was the adverse competitive effects resulting from applicant's prior ownership of these six subsidiaries.

The Board first considered the effects of the proposal on downtown St. Louis banks. It was noted that the largest of applicant's six St. Louis area subsidiaries, the $\$ 160$ million Bank of St. Louis, was also one of but four downtown St. Louis banks. Among these banks, the Bank of St. Louis ranked fourth. With the acquisition of First National, the second largest of the four banks, General Bancshares' share of the deposits of downtown St. Louis banks would increase from eight per cent to forty-three per cent. The number of independent banking organizations in the downtown area would be reduced from four to three.

The opinion also mentioned that in I950 there had been nine commercial banks in the downtown area and that the merger during 1965 between the largest of the St. Louis banks, the Mercantile Trust, and the fifth largest, Security Trust, had reduced the number of downtown banks from five to four. The Mercantile-Security merger had been approved by the Comptroller of the Currency but was subsequently challenged by the Department of Justice and is presently before the courts. The Board in its competitive factor report to the Comptroller of the Currency had viewed the competitive effects of the Mercantile-Security merger as eliminating existing and potential competition and as significantly adverse. At the time of the General Bancshares proposal, Mercantile accounted for forty-five per cent of the downtown deposit total.

In evaluating the competitive effects of the proposal on the structure of downtown St. Louis banks, the Board viewed adversely the amount of competition eliminated between the bank to be acquired and applicant's existing downtown subsidiary; the Board also expressed concern about the relative size distribution of the four banks. In terms of total deposits, if the largest bank is set equal to roo, the four-bank distribution equaled 100, 77,28 , and 17 and would have been changed as a result of the proposal to a three-organization structure with relative sizes roo, 94, and 28 .

The opinion recognized that the downtown market structure, when separately considered, was primarily relevant to the wholesale banking market, that is, the market serving the large national and international corporate customers. In this market, extensive intercity and interstate bank competition exists so that a small number of local alternatives is not of critical importance. It was concluded, however, that the proposal joining the second and fourth largest of the downtown St. Louis banks could have a detrimental effect on the "competitive force and position of the third wholesale bank in the area." 
Although the Board accepted applicant's view that the bank to be acquired was principally engaged in "wholesale banking" activities, it also found that First National was competing with the largest of applicant's subsidiaries, the Bank of St. Louis, for the business of medium-sized and smaller businesses in the downtown St. Louis area. It concluded that this "significant competition between First National and Bank of St. Louis ... would be substantially, if not wholly, eliminated if the acquisition proposed were permitted."

With respect to retail banking services, that is, services to households and smaller businesses, the Board found that First National was also a strong competitor in this field and competed with all of applicant's six subsidiaries in St. Louis and St. Louis County. The opinion cited statistics as to the number and average dollar balances of accounts obtained by First National from the areas immediately adjacent to each of the six subsidiaries. The Board concluded that although large wholesale banks "may compete for certain accounts that are not available to smaller institutions, large banks generally, including those in St. Louis, are "full-service' institutions" and compete with the smaller so-called neighborhood banks. For this reason also, the Board viewed the proposal as eliminating competition between all of applicant's St. Louis subsidiaries and the bank to be acquired.

In appraising market structure effects in St. Louis and St. Louis County, the Board observed that the bank to be acquired was the second largest of sixty-seven banks in the area and held nineteen per cent of the deposits. Applicant's six subsidiaries accounted for a combined seven per cent of these deposits. The proposal, therefore, would have increased the area share of General Bancshares to twenty-six per cent of the deposits of banks in this area.

Although the Board's appraisal of the effect of the proposal on retail banking competition considered both the competition to be eliminated between applicant's subsidiaries and First National and the increase in concentration, the opinion also expressed concern about the substantial size disparity between the large and small banking organizations in St. Louis and St. Louis County. The Board concluded that the proposal would "tend to increase still further [the larger banks'] competitive advantage over the smaller institutions."

The Board's over-all conclusion as to competitive effects was that the proposal was "sufficiently anticompetitive that the application may not be approved unless such anticompetitive effects are clearly outweighed in the public interest by the probable effect of the transaction in meeting the convenience and needs of the area to be served."

The applicant had contended that there was a need in the St. Louis area for "another bank ... of sufficient size to make a major contribution toward the development of a healthy economy for the St. Louis area." The Board rejected this argument with the statement that it was "not supported by either the evidence of record 
or by other evidence available to the Board." The opinion specifically noted that studies dealing with the determinants of plant location had indicated that factors other than the availability or size of local banking facilities or services were of considerably more importance. With respect to other arguments by the applicant relating to convenience and needs, the Board concluded that "the record does not reflect a need for banking services in the St. Louis area which are not presently available through the banks located there."

\section{B. The Effect of Structural Limitations in Merger and Holding-Company Cases}

Both the General Bancshares and the Wells Fargo-Sonoma opinions are illustrative of Board denials of merger and holding-company proposals which were found to involve substantial adverse competitive effects. The four cases to be considered next all resulted in approvals. In each of these cases, structural limitations on branching considerably mitigated anticompetitive effects that otherwise might have been sufficient to result in denials or at least in much closer decisions in favor of approval. Structural limitations on branching, therefore, not only prevent de novo entry and resulting increases in competition but also adversely affect the procompetitiveness of merger and holding-company regulation.

\section{r. St. Joseph Valley-First Old State S $^{39}$}

The substantial anticompetitive effects sometimes imposed by structural limitations on branching are illustrated by this $x 966$ case in which the Board very reluctantly approved the merger of the second and third largest of the three banks in Elkhart, Indiana. Particularly notable was the frank and clear statement by the Board's majority that Indiana law, which both confined branching within county boundaries and prohibited holding companies, left the Board no alternative but to approve a merger which would have a substantially adverse effect on competition. Approval was decided upon but with the statement that "there is no feasible alternative solution" to the capital and management problems of the acquired bank. In the absence of structural limitations on branching and holding companies, many less anticompetitive alternatives would have been available to the acquired bank, and the Board majority would not have felt compelled to agree to the reduction of commercial banking alternatives in Elkhart from three to two.

The acquiring bank in this case was the St. Joseph Valley Bank with deposits of $\$ 60$ million and a thirty-four per cent share of total deposits of Elkhart's three banks; the acquired bank, First Old State, with deposits of $\$ 19$ million, accounted for eleven per cent of the Elkhart deposit total. With but one minor exception, all of the offices of both banks were either in the City of Elkhart itself or very close to

\footnotetext{
${ }^{30}$ St. Joseph Valley Bank, 52 Fed. Reserve BuLl. 1765 (1966).
} 
the city boundaries. The one exception was a branch of the acquiring bank in a small community eleven miles to the south of Elkhart. As might be expected, the Board found that the principal impact of the merger would be on the City of Elkhart and did not find that any banks outside Elkhart were substantial competitors of the local banks. The Board, therefore, was faced with a merger with rather obvious and also serious structural consequences.

Although the Governors were not unanimous in approving the merger, all agreed that the effect of the merger on competition would be substantially adverse. The majority, moreover, specifically noted that "a merger with anticompetitive effects of the magnitude that are present in this case may not be allowed under the amended Bank Merger Act unless the adverse effects for competition would be 'clearly outweighed in the public interest by the probable effect of the transaction in meeting the convenience and needs of the community to be served. "\$0

Under the amended statute, capital and management problems were relevant to balancing effects on competition and on convenience and needs "to the extent that 'they throw light on the capacity of the existing and proposed institutions to serve the community." "41 In appraising the capital and management problems of the acquired bank, the Board cited inadequate capital, "loan losses that are attendant upon the imprudent lending policies of Old State Bank," and an inability of directors to reform lending policies because the chief operating officer was both the largest stockholder and "the dominant force in the bank." They concluded that "unless corrective action is taken, the bank is headed for serious capital and management problems."

In the ordinary case, this evaluation would be more than sufficient to justify merger with almost any bank willing to take on the problems of the acquired bank. The problem encountered by the majority was stated as follows:

State law prohibits branching across county lines .... Thus, the only other possibilities for Old State Bank to be acquired by merger lie with two Elkhart County banks, the larger of which has deposits of about $\$ 6$ million. Due to the small size of these banks, a merger with one of them would not materially alter the prospects for Old State Bank. Finally, State law also precludes the acquisition of Old State Bank by a bank holding company.

Given the need for merger, the Board majority was forced, however reluctantly, to decide whether potentially adverse effects on convenience and needs from allowing the bank to deteriorate further would outweigh the admittedly adverse effects on competition resulting from reducing the number of banks serving Elkhart from three to two. The majority ruled:

\footnotetext{
${ }^{20} 1 d$. at 1767 , quoting H.R. REP. No. 1221, 8gth Cong., 2d Sess. 4 (1966).

"1d.
} 
The merger would eliminate an alternative source of banking services from the Elkhart community, but it would also result in an orderly disposition of the problems that beset Old State Bank. The adverse competitive consequences of the merger could be minimized at some point in the future if Indiana should decide to change the restrictions on the establishment and operation of branch banking offices. On the other hand, the adverse impact on the community if the condition of Old State Bank should ultimately decline to failure could not be so easily minimized and, indeed, probably could not be materially lessened at all.

When situations such as that in the Elkhart case arise in the administration of the Bank Merger Act, restrictions on branching and holding-company activity frequently produce market structures with few actual and potential competitors. Since the banking industry is generally characterized by very high customer loyalty and is an industry in which medium-sized and smaller business customers are often reluctant to change banks for fear of jeopardizing credit relationships, new entry by either existing or newly-organized banks into a market area is always difficult. But if it is necessary to permit a substantial share of the market to be acquired by a bank competing in the same market simply because branching limitations and holding-company prohibitions deny entry to all but newly-organized banks, it is even more difficult than would ordinarily be the case to achieve a market structure with an adequate number of effective competitors.

\section{County Trust Company-Goshen National Bank and Intercounty Trust Com- pany $y^{42}$}

These mergers, approved in a combined opinion in January 1966 , are of interest not only because approval might not have been given in the absence of home office protection but also because they illustrate the frequently encountered barriers to entry resulting from home office protection and the importance of these barriers in regulatory agency appraisal of the competitive effects of mergers. This case also suggests the high price that independent banks are able to exact from purchasers in those states which restrict branching to the extent that merger constitutes the only means of securing desirable branch locations.

The cases involved simultaneous applications from the $\$ 73$ million County 'Trust Company of White Plains, New York, the largest bank headquartered in Westchester County, to acquire two small banks in neighboring Orange and Sullivan counties. At the time the application was made, County Trust operated forty-nine offices in Westchester County but none in either Orange or Sullivan counties. All of the banks involved were located within the same New York banking district. Branching in New York State is permitted on a district-wide basis, but New York law affords home office protection so that County Trust would not have been able to branch de novo into the head office community of either of the acquired banks.

\footnotetext{
${ }^{12}$ County Trust Co., 52 Fed. Reserve Buzu. $x 89$ (1966).
} 
The Board also observed that County Trust was precluded by home office protection from branching de novo into any of the more desirable locations in Orange and Sullivan counties.

The larger of the acquired banks, the $\$ 23$ million Intercounty Trust Company, had its head office in Monticello, a town of 5,000. The bank also operated two branches. The only other bank in Monticello was a single-office bank with deposits of \$I million. The Sullivan County area served by the acquired bank was described as a resort area but one in which year-round activities were increasing. The Board also noted that "intensive competition in the resort industry requires the constant improvement and expansion of facilities, causing a chronic condition of credit tightness that has been aggravated by attempts to diversify the economy of the County."

The other acquired bank, the $\$ 5$ million Goshen National Bank, had its sole office in Goshen, a community of about 4,000. In Goshen it competed directly with a larger commercial bank with deposits of \$I4 million and with a savings bank with deposits of \$I million. The area served by the bank to be acquired consisted of the central portion of Orange County with an estimated population slightly less than I9,000. The Board described the county as experiencing substantial growth since $195^{\circ}$ and as having favorable prospects for future growth. It noted that "the rate of growth of Orange County is expected to surpass that of the [New York] metropolitan area."

With respect to convenience and needs, parallel considerations were cited in the Board's discussion of both applications. The Board regarded both Orange and Sullivan counties as credit deficit areas:

The rapid expansion of Orange County has given rise to a corresponding need for the expansion of banking credit. Goshen Bank's size has not permitted it to keep pace with this expansion, nor does the bank offer a number of banking services that would help meet the needs and promote the convenience of the public and the communities in the area. The bank has a legal lending limit of $\$ 46,000$. Most of its real estate loans are for moderate amounts on existing structures, and it makes no FHA or VA mortgage loans.

In discussing the other acquired bank, the Board noted that Intercounty Trust,

with a lending limit of $\$ 157,000$, has not been able to satisfy the numerous demands made upon it for credit. The bank has followed a policy of making loans only to applicants who already maintain accounts with it and has declined, in recent years, a large number of credit-worthy applications. Intercounty, like Goshen Bank, makes no FHA or VA loans, but this is not unusual in either Sullivan or Orange Counties. Indications are that the deficit of credit in these areas is likely to continue in coming years.

From the point of view of convenience and needs, County Trust, as the largest bank in the Third District, could certainly be expected to improve the level of bank 
services and the supply of credit in the areas served by the acquired banks. The Board accordingly found,

There is a need in both Sullivan and Orange Counties for an increased supply of credit and other banking services, which Goshen Bank, Intercounty, and the other locally-based banks have not been able to supply. The entry of County Trust into these Counties should help meet the need for additional credit ....

In evaluating the competitive effects of the proposal, the Board opinion made three principal points: ( $\mathrm{x}$ ) the proposal would not eliminate existing competition between the three banks; (2) although County Trust, the leading bank in the Third District, accounted for twenty-nine per cent of total deposits of Third District banks, the proposal would not increase this percentage significantly; and (3) smaller banks remaining in Orange and Sullivan counties "should encounter little difficulty in achieving continued growth and vitality."

In the absence of home office protection, considerations relating to the need for immediate improvements in convenience and needs might not have been compelling enough to persuade the Board to permit the largest bank in the Third District to expand by merger rather than by de novo branching. The Third District, consisting of seven counties in New York State on both sides of the Hudson River north of New York City, is not of course at present a single market. None of the more than fifty-five Third District banks operate on a district-wide basis, and none are likely to be able to do so because of the extensive number of communities not open to de novo branching because of home office protection. Without this restriction on branching, however, the Third District might become much more of a potentially relevant market for at least the largest banks in the District, and the Board might well have been persuaded that the largest of Third District banks with deposits of $\$ 73$ I million, or twenty-nine per cent of the District total, should not be permitted to expand by merger into particularly favorable locations prior to the entry of somewhat less formidable competitors.

Since New York State permits holding companies to operate on a statewide basis, improvements in the banking services available in the areas served by the two acquired banks could alternatively have been secured by a holding-company acquisition of these banks. Acquisition by a holding company could conceivably have resulted in no increase in Third District concentration if none of the holding-company affiliates had operated within the district. This alternative, however, like the possibility that the two banks could have been acquired by smaller Third District banks, would probably have been too problematical a basis for denying the actual proposal since no such alternative had been presented.

This case also illustrates the price that must be paid by banks seeking to extend their markets in order to overcome the barrier to entry resulting from home office protection. As pointed out by Governor Robertson in his dissent, County Trust 
paid substantial premiums over book value for each of these banks. These amounted respectively to seven and nine per cent of the deposits of the Intercounty and Goshen banks. In the case of Goshen, for example, stockholders received County Trust stock equal to almost double the book value of their original stock. Book value is not always a fair indicator of market value, but the premium in this case is suggestive of the scarcity value of home office protection.

\section{New Jersey Bank and Trust Company-Wayne State Bank $k^{43}$}

If the County Trust cases illustrate the anticompetitive effects of home office protection at their mildest, the Wayne State case of 1965 is an example of their much more important consequences. Moreover, there is little doubt in this case that, in the absence of home office protection, the Board would not have allowed the largest bank in Passaic County, New Jersey, to expand by merger.

The case involved the acquisition of the $\$ 8$ million, three-year-old Wayne State Bank of Wayne, New Jersey, by the \$3rg million New Jersey Bank and Trust Company. Wayne Township is located in North Jersey and occupies the middle section of Passaic County. The two offices of the acquired bank served a portion of Wayne Township. As viewed by the majority, most of the township's banking needs were being met by two Wayne Township offices of the county's second largest bank, the $\$ 280$ million First National Bank of Passaic County, which also operated all of the banking offices in Passaic County to the north of Wayne Township. No other banks, aside from the acquired bank and First National, operated offices in Wayne Township.

The acquiring bank operated no offices in the township itself but did operate several offices near the border of Wayne Township to the south. The principal issues in the case were these: First, to what extent did the convenience and needs of Wayne residents and businesses require a more effective local alternative to First National? And, second, to what extent would acquisition of Wayne State by the largest bank in the county, a bank already competing to a limited extent with the bank to be acquired, be consistent with statutory standards with respect to competitive effects?

Home office protection figures prominently in this case because under New Jersey law no bank but Wayne State or a new bank headquartered in Wayne Township could establish de novo branches in the township. New Jersey law permits countywide branching but also specifies that "only a bank headquartered in a municipality can establish a de novo branch there if any other bank already has an office in the community."

With respect to convenience and needs, the Board's majority found that Wayne State, which had been operating for more than three years, was not meeting the credit needs of Wayne businesses and households. The majority observed that Wayne State

\footnotetext{
${ }^{48}$ New Jersey Bank \& Trust Co., 5I Fed. Reserve Burl. I269 (I965).
} 
has no FHA or GI mortgages, and has generally avoided committing bank funds in the mortgage market. Such few mortgages as it has made were accommodations to customers connected with the board of directors. It has made few automobile loans in the community, preferring to purchase paper from other institutions. Indeed, it has followed a similar policy as to all loans, originating only a minor portion in Wayne, obtaining some from directors' contacts outside the community, and purchasing a large majority. In sum, only about 20 per cent of the bank's total loan volume is derived from its own community.

Wayne State's inability and unwillingness to serve local residents was compounded by the fact that it was located in a township which was one of the most rapidly growing areas in the county. The bank, moreover, had secured permission to operate a branch in a projected shopping center which it was claimed would be the world's largest. Home office protection had given Wayne State exclusive rights to apply for a branch in the shopping center.

From the point of view of convenience and needs, the Board could well regard the acquiring bank, which was also the largest bank in the county, as a particularly well qualified candidate to take over the two offices of Wayne State and to provide an adequate local alternative to First National's Wayne offices.

From the competitive point of view, however, the case presented some serious issues. The Board majority recognized this and observed as follows:

It is a disturbing factor in the competitive picture that effectuation of the proposal would increase, although to an insubstantial extent, the proportion of county loans [38.2 per cent] and deposits [36.5 per cent] held by the slightly larger of the two largest banks in Passaic County. ... Banking concentration in the county will be increased, and the only small independent bank in an area dominated by First National will disappear.

An additional consideration was that Jersey Bank from its offices close to Wayne was also competing to a limited extent in the area served by the acquired bank. The Board, however, attributed this competition more to the failure of Wayne State to offer a real alternative to First National than to the ability of Jersey Bank to compete in the Wayne area.

The answer of the Board to the possible anticompetitive structural effect of the merger rested on the argument that while it might be desirable to permit a bank other than Jersey Bank to acquire Wayne State, home office protection would bar a de novo entry by Jersey Bank, the county's largest bank. Implicit was the further argument that none of the smaller banks would be large enough or aggressive enough to compete with First National in providing banking services to Wayne residents. The Board, for example, had specifically taken note of First National's aggressive competitive tactics.

In the absence of home office protection, a quite different line of reasoning might have been followed, one that could have resulted in denial. A decision to deny could 
have been based upon the reasoning that the acquiring bank as the leading bank in the county and as a bank with offices quite close to the area served by the Wayne State Bank was the most probable and capable of the potential entrants into Wayne Township, especially since the second largest of the Passaic County banks already operated offices within Wayne Township. Given the almost seventy per cent share of county deposits accounted for by the two largest banks, it could have been further argued that growth by merger for the largest bank would have been incompatible with assuring in the long run a reasonable number of competitors for the Wayne area and a relative balance among the county's banks. Certainly, a more vigorous competitive climate in the Wayne area would have resulted if one of the five smaller Passaic County banks had merged with Wayne State and Jersey Bank had entered de novo. At the very least, the Wayne area would have been locally served by three competitors.

A final point illustrated by this case is again the scarcity value created by home office protection. In his dissenting statement, Governor Maisel noted that the premium over book value paid to Wayne State shareholders was "the highest ever to come before the Board in a merger application."

\section{Charter New York Corporation ${ }^{44}$}

The Board's approval in April I 966 of the formation of a new holding company, the Charter New York Corporation, is a holding-company case that illustrates the way in which restrictions on branching diminish opportunities to effect increases in the number of competitors serving a major city even when the need for such increases is acknowledged by the regulatory authority. The case involved the formation of a holding company to include the $\$ 2.6$ billion Irving Trust Company of New York City and the \$r 3 million Merchants National Bank and Trust Company of Syracuse. Under New York law, holding companies are permitted to operate statewide, but branching, as mentioned earlier, is limited by both home office protection and the division of the state into nine districts with a prohibition against interdistrict branching. As a consequence, Irving with offices in the First District and Merchants with offices in the Sixth District were prohibited from merging with each other. They could, however, attempt to form a holding company.

In evaluating the Charter proposal, the Board at the outset dismissed any possibility that the convenience and needs of the New York City area would be significantly affected by the proposal. The majority felt, however, that the Charter proposal offered somewhat greater possibilities for gains in convenience and needs in the Syracuse area.

Five commercial banks operated offices in Syracuse, a city with population in excess of 200,000. Merchants ranked fourth among these banks and accounted for

\footnotetext{
"Charter New York Corp., 52 Fed. Reserve Bull. 527 (1966).
} 
about eighteen per cent of their deposit total. The deposits of the smallest of the five Syracuse commercial banks amounted to $\$ 7$ million or less than six per cent of the Merchants total. The four largest accounted for ninety-nine per cent of the five bank total and varied in deposit size from \$rII million to \$222 million. Also headquartered in Syracuse were two large savings banks, each with deposits in excess of $\$ 200$ million. Three additional commercial and savings banks operated offices in Onondaga County, which both includes and surrounds Syracuse. All three, however, were relatively small institutions, and only two were actually headquartered in Onondaga County.

Deposits of Commercial Banks Headquartered in the City of Syracuse and in Onondaga Countx, New York, June 30, x965

\begin{tabular}{|c|c|c|c|}
\hline Name of bank & $\begin{array}{l}\text { Total deposits } \\
\text { ( } \$ \text { thousands) }\end{array}$ & $\begin{array}{c}\text { Per cent } \\
\text { distribution } \\
\text { for Onondaga } \\
\text { County }\end{array}$ & $\begin{array}{c}\text { Per cent } \\
\text { distribution } \\
\text { for } \\
\text { Syracuso only }\end{array}$ \\
\hline $\begin{array}{l}\text { Syracuse Banks: } \\
\text { First Trust and Deposit Company }\end{array}$ & 222,404 & 30.3 & 30.7 \\
\hline $\begin{array}{l}\text { Manne Central New York } \\
\text { Lincoln National Bank and Trust Company }\end{array}$ & $\begin{array}{l}198,630 \\
165,247\end{array}$ & $\begin{array}{l}27.0 \\
22.5\end{array}$ & $\begin{array}{l}27.3 \\
22.8\end{array}$ \\
\hline $\begin{array}{l}\text { Merchants National Bank and Trust } \\
\text { Company } \\
\text { Metropolitan National Bank }\end{array}$ & $\begin{array}{r}130,632 \\
7,319\end{array}$ & $\begin{array}{r}17.8 \\
1.0\end{array}$ & $\begin{array}{r}18.0 \\
1.0\end{array}$ \\
\hline City of Syracuse, Total & 724,232 & 98.6 & 100.0 \\
\hline $\begin{array}{l}\text { Other Onondaga County Bank: } \\
\text { Solvay Bank, Solvay }\end{array}$ & 10,685 & 1.4 & \\
\hline Onondaga County, Total & $\$ 734,917$ & 100.0 & \\
\hline
\end{tabular}

Source: PoLE's BANE Directory, September 1965.

The very small number of commercial banks in the Syracuse area lent some plausibility to applicant's assertion that the proposal would benefit convenience and needs. By means of the holding company, Merchants would be linked with the great banking expertise of the seventh largest bank in New York City. This could be expected to improve the capacity of Merchants to offer service competition to its larger Syracuse rivals. Possibilities for improvement with respect to credit services, however, were somewhat limited since the second largest of the Syracuse banks was an affliate of the Marine Midland Corporation, a statewide holding company with total deposits of $\$ 3$ billion, and was therefore able to service the credit needs of even the largest borrowers in the Syracuse area.

The applicant had urged that the proposal would specifically provide three principal benefits: (I) "a necessary, alternative source of funds to meet existing and anticipated credit demands of the area's commercial and industrial concerns"; (2) "rendition of more extensive and specialized international banking services"; and 
(3) "expansion of Merchants' service offerings in the personal and corporate trust fields."

In evaluating the first of these points, the Board did not accept the argument that the holding-company mechanism would be sufficiently superior to correspondent arrangements to result in real improvement in credit available in the Syracuse area. The majority specifically noted first that "with regard to the need in the Syracuse area for additional or improved credit sources, notwithstanding the significant economic expansion that has occurred and is likely to occur in the Syracuse area, the Board is unable to concur in applicant's position that any substantial deficiency exists in this respect." They also rejected the claim that future credit needs in the Syracuse area could not be met through correspondent arrangements, normal deposit growth, and the projected capacities of the existing Syracuse banks, which included, of course, the Marine Midland affiliate.

With respect to the application's second major area of promised improvements, that is, international services, the Board's majority was considerably more enthusiastic. They concluded that, "while bank services normally incident to export activity are now available in the Syracuse area, either directly from the banks located there or through their correspondent banks in New York City, Irving's extensive experience in all aspects of international banking would, in the Board's judgment, constitute an immediate and significant contribution to the area's requirements."

The third major promised improvement was in the area of trust services. The majority stated that

the record fails to establish that Merchants is not presently responding adequately to the apparent limited demand made of it for corporate trust, investment, and related services, all of which Applicant states it is ready to provide to or through Merchants. It is the Board's judgment that any limitation on that bank's ability to provide such services, either now or in the future, is negligible and does not require assistance from outside the bank for solution.

In summary, the Board's majority found some gains to convenience and needs in the area of international services but that no other significant improvements in convenience and needs were offered by the proposal. With so weak an improvement in convenience and needs, it would not have taken very great anticompetitive effects to result in a denial recommendation. The Board found no such effects, principally because of limitations on bank structure resulting from the New York State branching regulations.

In considering competitive effects, as was the case in the consideration of convenience and needs, the majority dismissed any possibility that the proposal would affect competition in the New York City area. With respect to the Syracuse area, the Board indicated concern that "a substantial portion of the total banking resources in Onondaga County is concentrated in a few large banking institutions-a considera- 
tion of some moment to this Board." The Board, however, found that the proposal would not eliminate existing or potential competition. The opinion stated that

there is no evidence of any existing significant competition between [Irving and

Merchants], nor is there likelihood that such will develop in a foreseeable future.

The nearest offices of the two banks are separated by some 270 miles. The State

law prohibits either from opening branch offices in the other's banking district.

The majority opinion omits discussion of the potential competition that could have resulted from Irving's entry into the Syracuse area by affiliating with a newlyorganized bank. By implication, at least, the Board majority in this case regarded de novo branching as the only realistic source of new entry. If New York State law had permitted statewide branching, the Board majority opinion holds out the possibility that they might have concluded that Irving, a \$2.6 billion bank, had the capacity to branch de novo, thereby providing Syracuse with an additional competitor and with the apparently needed international services.

With a finding that the proposal would eliminate neither existing nor potential competition, the Board majority could then place major emphasis on the benefits to competition from the proposal. They concluded that "it is reasonably anticipated that the affiliation of Merchants, the smallest of the six major [commercial and savings] banks headquartered in Syracuse, with Irving will enable Merchants to offer more meaningful competition to its numerous larger competitors for the deposit and loan accounts of the area's major commercial and industrial concerns." This finding constituted the sole competitive benefit of the proposal specified by the majority. The Board also considered possible adverse competitive effects on the three smaller commercial and savings banks operating in Onondaga County and on correspondent relationships. No such anticompetitive effects were noted. Approval of the proposal, therefore, rested on some improvement in convenience and needs as a result of the provision of international services and some increase in competition for banks larger than Merchants in the Syracuse area.

\section{$\mathrm{V}$}

\section{ConcLusion}

In most merger and holding-company cases, the primary factor weighed by the federal bank supervisory authorities has been the impact upon the competitive situation. The cases reviewed have illustrated some aspects of the relationship of stateimposed branching and holding-company limitations to the problem of achieving procompetitive solutions in acting upon specific merger and holding-company proposals. Of these cases, the Elkhart approval probably represents the most explicit statement by the Board that these limitations often force approval of an anticompetitive merger in order to resolve serious capital and management problems. In the Elkhart case, approval reduced the number of locally available banking alternatives from three to two. 
In the County Trust cases, the conflict between maintaining competitive market structures and branching limitations in the form of home office protection was considerably less severe because the merger represented a market extension rather than a merger of banks serving the same market. Unlike the Elkhart case, the effect in these cases of branching limitations was not to reduce the number of competitors serving a local market. Restriction of de novo entry, however, was important in the County Trust cases as a justification for approval of market extension through merger by a fairly large bank. When, as is often the case, such large banks are the most likely potential entrants on a de novo basis, the probable long-run effect of home office protection is to reduce the number of competitors serving a given market.

The Wayne State case similarly illustrates the anticompetitive effects of branching limitations but does so with more certainty. In this case, the majority opinion recognized the already high concentration in the New Jersey county, the leading position of the acquiring bank, and the fact that it was already competing to a limited extent in the area served by the acquired bank. There was in addition little doubt that absent home office protection the acquiring bank would also have been the most probable of potential entrants by means of de novo branching. Given these factors, denial of the merger, rather than approval, would probably have resulted if more liberal branching regulations had been in effect.

Although statewide branching in many states has permitted the development of highly concentrated banking structures, branching restrictions are no longer needed to prevent undue concentration of banking at the state level. The Bank Holding Company and Bank Merger acts can now be relied upon as effective barriers to excessive concentration resulting from the acquisition of existing banking organizations. The Board denials in Wells Fargo-Sonoma and General Bancshares are evidence of the operation of these barriers. Justice Department challenges of mergers approved by the bank supervisory agencies may be regarded as an additional safeguard. Branching restrictions and the prohibition of holding-company activities rather than preventing excessive concentration are currently more often than not an obstacle to achieving more competitive market structures at the local level. In effect, therefore, any state which now restricts branching or holding companies has the opportunity to create a considerably more competitive banking structure by liberalizing such restrictions and thereby encouraging de novo branching and increasing the possibilities of procompetitive solutions to Elkhart-type problems.

Supervisory policy at both the federal and state levels permits a good deal of diversity in banking market structures with respect to bank size, degree of concentration, and other characteristics. Alternatively, however, the supervisory agencies could attempt to achieve substantial reductions in the average size of banks and the degree of local market concentration by vigorously encouraging the entry of new firms into the banking field and severely limiting the expansion of existing firms in those markets characterized by a high degree of concentration. Or, they could move 
in the opposite direction and encourage the expansion of existing firms into a relatively few branch banking systems.

The first alternative would require easier entry requirements than at present. Perhaps consideration would be given only to requiring minimum capital and adequate management characteristics, leaving it to business judgment to determine the earnings prospects. Competition with weak and inefficient banks would be encouraged, and provision would be required for the orderly liquidation of those units which were unable to meet competitive pressures. This approach would be consistent with the encouragement of small local branch systems and their expansion through de novo branching. It would, however, require a careful screening of proposals by existing large branch and holding-company systems to expand by either the merger or the de novo route. This approach would go farthest in the direction of maintaining unit banks and small branch systems. It would tend to limit the economies of scale and the mobility of capital that might be derived from large branch bank systems. Furthermore, in some market areas the range and quantity of banking services available to customers would be limited by the size of banks that could operate.

At the other extreme, supervisory policy could take the direction of minimizing restrictions on mergers and branching. As suggested by the Commission on Money and Credit, ${ }^{45}$ consideration might be given to permitting bank branching to cross state lines where these bisect market areas. Such liberalization would move us in the direction of a banking system dominated by large branch banks. Presumably, however, the advantages of branching that exist would be fully utilized, flows of capital would be facilitated, and convenience in the availability of banking services would be maximized.

While the present results of banking market structure regulation may not be ideal, any sharp change in standards must be viewed cautiously until the advantages are clear. There are a great many questions to be answered and issues to be resolved before the most desirable banking structure characteristics can be determined as a guide to supervisory controls over banking structure. Required is a careful exploration of the nature and effectiveness of competition within present banking markets. An important question still under debate is whether banks compete in a number of different product markets or whether their basic output is primarily a package of services distributed within a single market. Economies of scale in banking and performance differences of unit, branch, and holding-company types of operation also need further study. With reasonably satisfactory answers to these questions there would be a basis for determining the changes needed in supervisory standards for banking structure regulation.

\footnotetext{
${ }^{12}$ Commission on Money and Credit, Money and Credit: Their Influence on Jobs, Prices, and Growth I64-66 (Report of the Comm'n on Money and Credit, I96I).
} 